\title{
Emissions from Waste Burning, Uneven Rainfall and Flood Events as Predictors of Climate Change Effects in a Nigerian Community
}

\author{
Hammed TB* and Sridhar MKC \\ Department of Environmental Health Sciences, University of Ibadan, Nigeria
}

Submission: January 26, 2019; Published: February 11, 2019

*Corresponding author: Hammed TB, Department of Environmental Health Sciences, Faculty of Public Health, College of Medicine, University of Ibadan, Ibadan, Nigeria.

\begin{abstract}
Flooding and waste management related problems have become matter of public health concern in the last few years in Ibadan, Nigeria. In this study, waste management activities at Kube-Atenda in Ibadan with a focus on greenhouse gases emissions (GHS), rainfall pattern and occurrence of flooding were investigated. Data were collected, using calibrated digital meters; portable global positioning system (GPS) device and ArcGIS 9.3 to developed maps of GHG distribution pattern in the community; Intergovernmental Panel on Climate Change (IPCC) model for GHG generation potential of solid waste burning in a year and, gamma and Weibull distribution for prediction of rainfall pattern and flooding in the area. The levels of GHGs reduced with distance away from the dump site and were higher than regulatory limits. Since $\beta=6.744$ is positive, in 3 years from 2014 upward, there could be flooding in the study area if there is no proper management plan.

Keywords: Greenhouse gases; IPCC-based model; Waste management activities; Flood prediction; Rainfall pattern; Ambient air quality

Abbreviations: GPS: Global Positioning System; IPCC: Intergovernmental Panel on Climate Change; GHGs: Green House Gases; AQI: Air Quality Index
\end{abstract}

\section{Introduction}

Extreme weather events accompanying anthropogenic activities and climatic changes have become topics of intense researches throughout the world. Flooding is common in Nigeria and news report depicts its occurrence in almost every raining season. Over the period 1985 to 2014, it has affected more than 11 million lives with a total of 1100 deaths and property damage exceeding US $\$ 17$ billion [1]. In 2012 alone, about 1.3 million Nigerians were displaced and 431 died from various flood occurrences [2]. In that same year, 30 of 36 Nigeria's states were affected by the floods [3]. The causes of floods in Nigeria have been linked to poor urban planning, poorly constructed drainage and climate change especially in unprecedented increased frequency and intensity of rainfall [4-8]. Other factors considered are urbanization and population growth, lack of early warning and evacuation systems, topography of the area, land use, soil type and land cover modifications [9-11]. In addition, poor environmental management and indiscriminate disposal of solid municipal waste have been implicated as a major contributor to flooding and other climate change related problems $[6,12]$. The waste sector contributes about onefifth of global anthropogenic methane emissions [13]. Apart from generation of greenhouse gases (GHGs), poor waste management affects public health and aggravates climate change effects such as flooding and epidemic of diseases.
It is argued that more robust and scientific approaches to flood risk mitigation such as: flood modeling and vulnerability assessment are lacking [1]. According to Shirmohammadi [14], precipitation with temperature are the most important and decisive climatic factors suitable for tracking climatic changes. Salahi et al. [15] used average of monthly precipitation to model precipitation characteristics and simulation of drought in Iran and found out that the average of monthly precipitation in the latter 10 years will decrease about $26 \mathrm{~mm}$ compared with the former 10 years (2001-2010). Kaoje \& Ishiaku [16] used HEC-RAS and GIS to conduct hydraulic modelling, flood inundation mapping and visualization of Lagos State and concluded that flood vulnerability of this kind is important for Nigeria and other countries to aid decision on flood disaster planning. To determine the spatial flooding situation and the degree of the city's susceptibility to flooding in Calabar, south-south of Nigeria, Inah et al. [17] used geographic information system to capture factors such as, sea level rise and increased annual precipitation, integrating them into a common geo-referenced model. Their study reveals that the study area just like all flood plains is highly vulnerable to flash floods. In a related study, Peter et al. [18], adopted Remote Sensing and Cellular Automaton Evolutionary Slope and River (CAESAR) model to determine inundation level and assess vulnerability of settlements 


\section{International Journal of Environmental Sciences \& Natural Resources}

in Adamawa State. Their flood analysis for low, medium and high flow regimes showed that an average of 134 settlements are at risk.

Flooding in Nigeria dates back to 1963 when Ogunpa River flooded Ibadan city causing loss of lives and properties with reoccurrences in 1978, 1980 and 2011 [19,20]. Previous studies reveal that Nigeria has poor flood warning and poor flood insurance

Materials and Methods scheme [21,22]. Hence, building resilience capability to cope with increasing climate variability remains the most viable option for flood management in Nigeria. The present study was therefore carried out to assess both natural and anthropogenic activities in a vulnerable community that can endanger lives of residents, including solid waste induced GHGs, impact of waste management on GHGs emissions and rainfall pattern, thereby predicting flooding occurrence in the area.

\section{Study area}

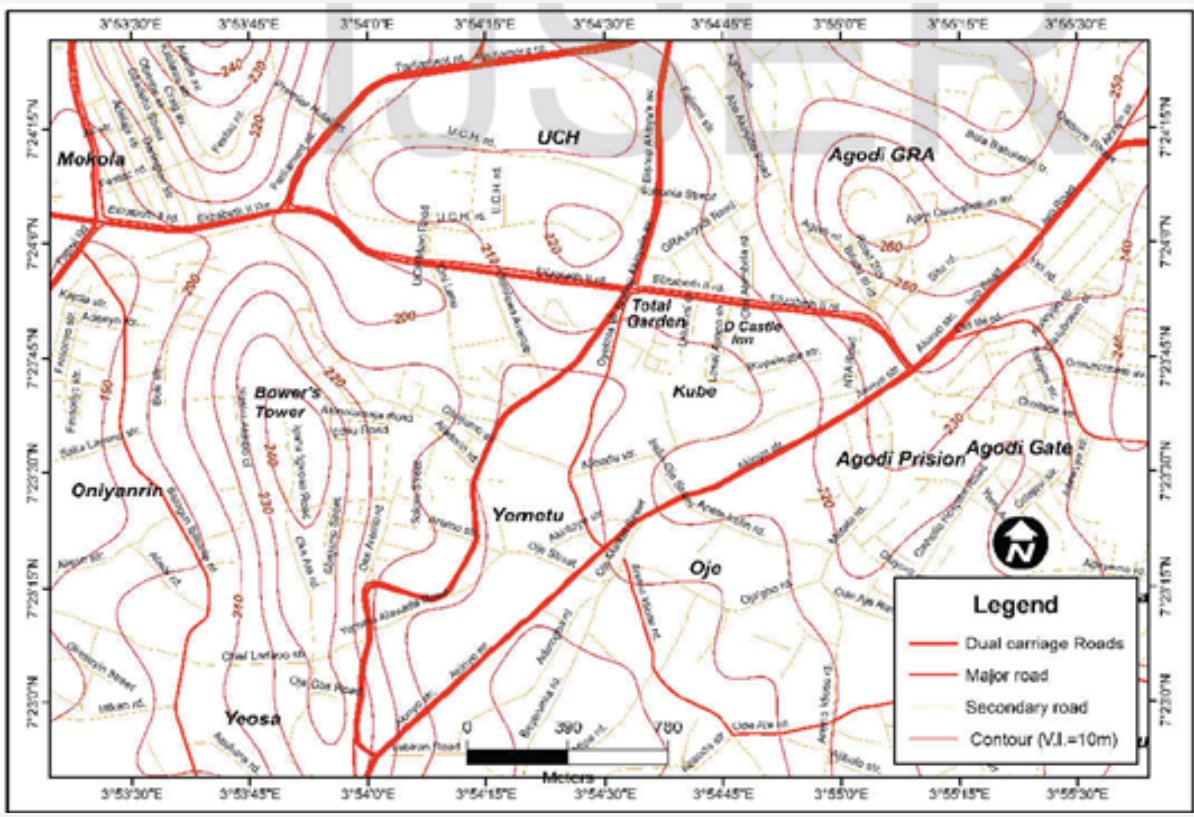

Figure 1: Topographical Map of Kube-Atenda.

(Source: Department of Geography, Faculty of the Social Sciences, University of Ibadan, Oyo State.)

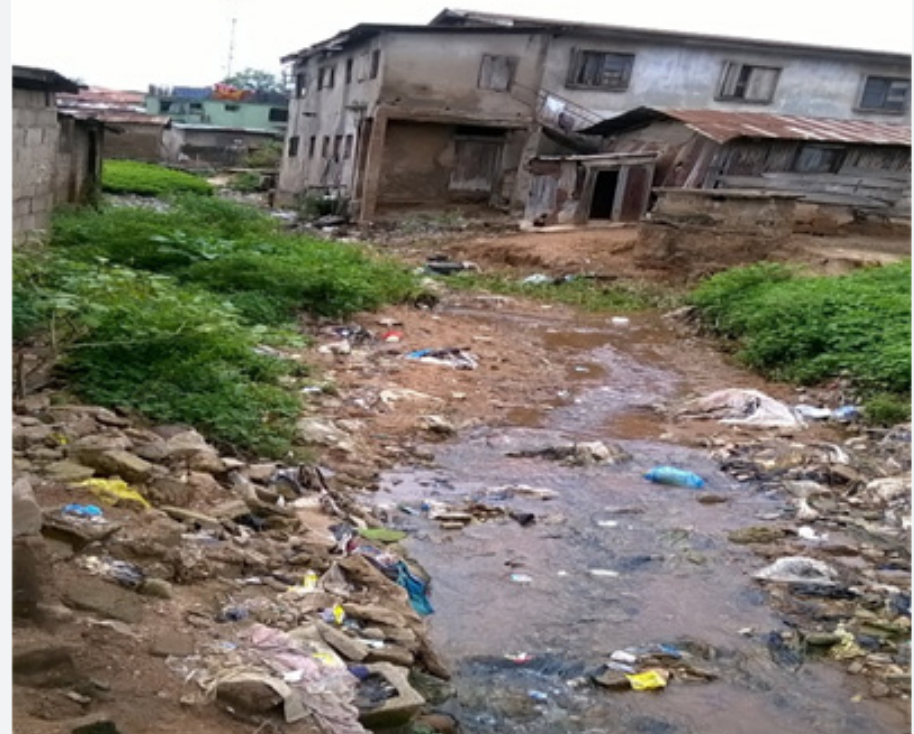

Figure 2: A stream in the community polluted with solid wastes. 


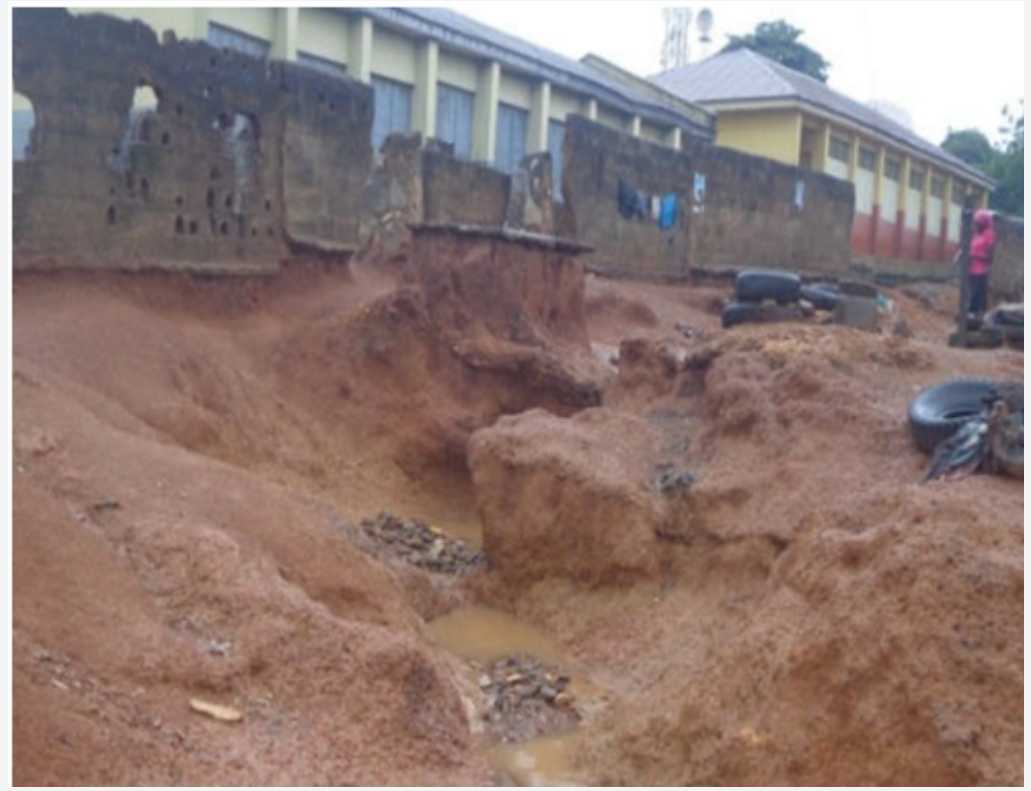

Figure 3: Section of community with gulley erosion.

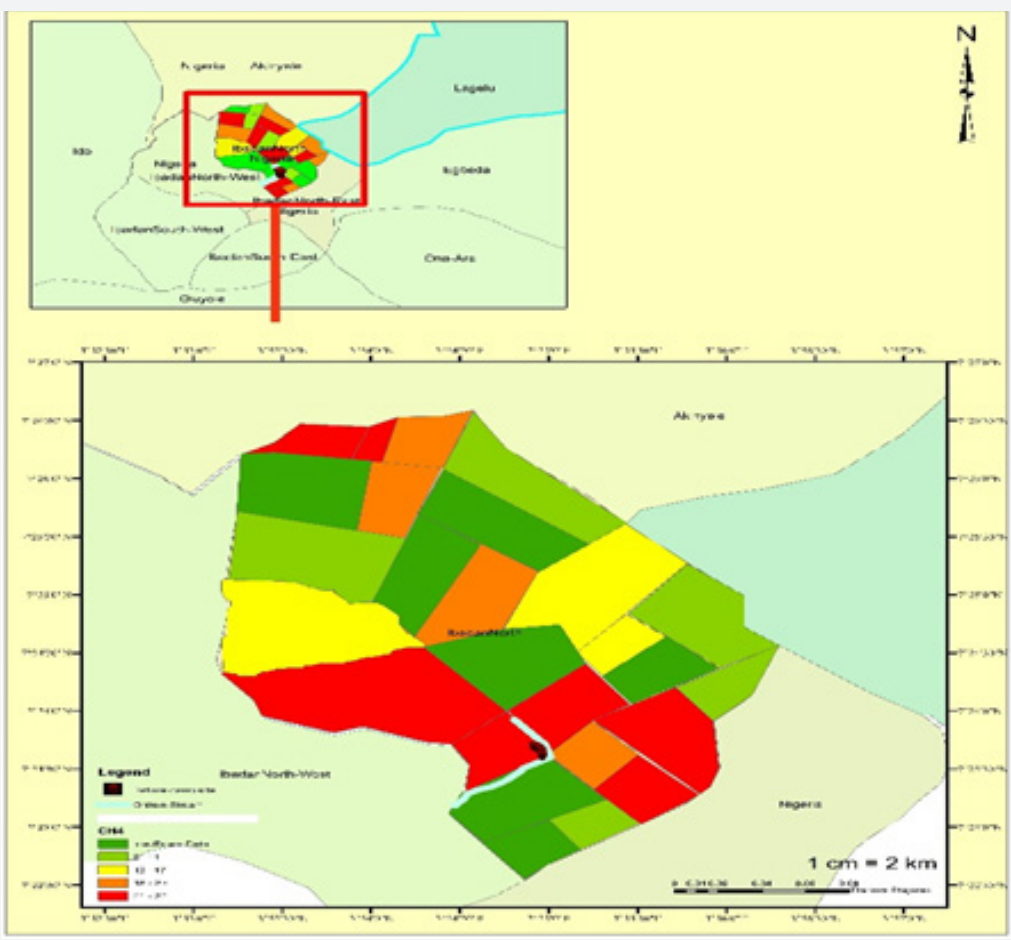

Figure 4: Pattern of $\mathrm{CH}_{4}$ distribution in the community

Kube-Atenda community is located within Agodi vicinity, along Queen Elizabeth II road in Ibadan North Local Government Area of Oyo State. It is centered on Latitudes $7023^{\prime}$ 0"N and $7024^{\prime}$ $15^{\prime \prime} \mathrm{N}$ and Longitudes 30 53'30"E and 30 53' 30"E. The main occupation of Kube-Atenda people is trading which has boosted the economic activity in the community. Few artisans such as welders, carpenters and cobblers are also present in the community. There are pockets of fertile grassland in the community where the resident's rear animals such as goat, sheep and fowl, and grow va- riety of crops such as maize, pepper, vegetables and others. The topography of Kube-Atenda community is generally flat due to the hilly/undulating nature of areas surrounding it [23]. The flatness of the area retards the flow of the surface runoff and prevents its rapid discharge to the main 'Alagbafo' stream that flows across the community while all the tarred roads in the neighbourhood slope downward to Kube-Atenda community. Purposive selection of Kube-Atenda community for this study was therefore based on its vulnerability to valley erosion (Figures 1-3). 


\section{Data collection procedures}

\section{Ambient air quality in the community}

Calibrated hand-held digital meters (P-Sense Plus $\mathrm{CO}_{2} / \mathrm{CH}_{4}$ and $\mathrm{NO}_{2} \mathrm{AZ}-7755$ meters) were used to measure ambient gaseous pollution parameters: $\mathrm{CO}_{2}, \mathrm{CH}_{4}$ and $\mathrm{NO}_{2}$ as well as temperature at various points across the community. A portable Global Positioning System (GPS) device was used to determine the geographic coordinates of the selected sites and ArcGIS 9.3 was used to developed maps of GHG distribution pattern in the community. Also, from the values obtained from digital meters, Air Quality Index (AQI) was computed to describe ambient air quality, using the following mathematical equation (Eq. 1) [24]:

$$
\text { AQI pollutant }=\frac{\text { data measured for each pollutant }}{\text { Standard }} \times 100
$$

The AQI was categorized as very good (0 -15), Good (16 -31), Moderate (32 - 49), Poor (50 - 99) and very poor (100 and over) [25]. The value obtained for each parameter at the centre of the community, specifically at $10 \mathrm{~m}$ away from dump site, (i.e. $\mathrm{CO}_{2}=$ $535.50 \mathrm{ppm} ; \mathrm{CH}_{4}=160,000.0 \mathrm{ppm}$ and $\mathrm{NO}_{2}=11.75 \mathrm{ppm}$ ) was used in the computation of AQI while the available standards used included: 4ppm for $\mathrm{CO}_{2}$ (The Kenyan environmental management and co-ordination (air quality) regulations, 2014) [26]; 0.14ppm for $\mathrm{NO}_{2}$ and $0.01 \mathrm{ppm}$ for $\mathrm{CH}_{4}$ [27].

Table 1: Values used in $\mathrm{CO}_{2}$ emission modeling in the community.

\section{GHG emission potential of solid waste burning}

The contribution of GHG into the environment in a year due to waste burning was estimated, using Intergovernmental Panel on Climate Change (IPCC) model [13]. In this model, default values and data from another study on waste characterization exercise in the community (Table 1 ) were used. Estimation of $\mathrm{CO}_{2}$ emission from open burning of waste (Eq. 2) was based on was based on the Tier 2a method of the Guidelines [13].

$\mathrm{CO}_{2}$ Emissions $(\mathrm{Gg} / \mathrm{yr})=\mathrm{MSW} \times \Sigma_{j}\left[W F_{j} \times d m_{j} \times C F_{j} \times F C F_{j} \times O F_{j}\right] \times \frac{44}{12} \ldots \ldots . . . \mathrm{Eq} .2$

Where MSW represents total amount of municipal solid waste as wet weight open-burned $(0.052 \mathrm{Gg} / \mathrm{yr})$; $\mathrm{WF}_{\mathrm{j}}$ is fraction of components such as: paper/cardboard, textiles, food remnant, and so on (j) in the waste (as wet weight open-burned); $\mathrm{dm}_{\mathrm{j}}$ is dry matter content in the component $\mathrm{j}$ of the MSW open-burned; $\mathrm{CF}_{\mathrm{j}}$ is fraction of carbon in the dry matter of component $j ; \mathrm{FCF}_{j}$ is fraction of fossil carbon in the total carbon of component $\mathrm{j}$; $\mathrm{OF}_{\mathrm{j}}$ is oxidation factor, 44/12 is conversion factor from $\mathrm{C}$ to $\mathrm{CO}_{2}$. Details of data used in the model are shown in Table 1 while the total amount of municipal solid waste open-burned was calculated using equation 3.

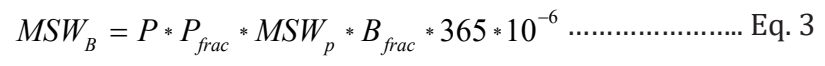

\begin{tabular}{|c|c|c|c|c|c|c|c|}
\hline S/N & Recyclable Waste Components & WFj (Hammed et al. [28]) & dmj & CFj & FCF & OF & Sum \\
\hline 1 & Organic & $19.70 \%$ & 40 & 38 & - & - & 299.44 \\
\hline 2 & Metal Scraps & $5.20 \%$ & 100 & - & - & - & 5.2 \\
\hline 3 & Plastics & $11.90 \%$ & 100 & 75 & 100 & - & 89250 \\
\hline 4 & Glass Bottle & $1.60 \%$ & 100 & - & - & - & 1.6 \\
\hline 5 & Nylon & $32.60 \%$ & 100 & 75 & 100 & - & 244500 \\
\hline 6 & Rubber/Leather & $6.20 \%$ & 84 & 67 & 20 & - & 6978.72 \\
\hline 7 & Textiles/Rags & $2.60 \%$ & 80 & 50 & 20 & - & 2080 \\
\hline 8 & Dust \& Ashes & $13.50 \%$ & 90 & 3 & 100 & - & 3645 \\
\hline 9 & Paper & $6.70 \%$ & 90 & 46 & 1 & - & 277.38 \\
\hline & Total & 100 & 784 & 354 & 341 & - & $347,037.34$ \\
\hline
\end{tabular}

Where: MSWB is total amount of municipal solid waste openburned in $\mathrm{Gg} / \mathrm{yr}$; $\mathrm{P}$ is population of people in the community $(10,000) ; \mathrm{P}_{\text {frac }}$ is proportion of population burning waste $(35 \%)$; MSWP is per capita waste generation which is $0.068 \mathrm{~kg} / \mathrm{cap} /$ day [28]; $\mathrm{B}_{\text {frac }}$ is fraction of the waste amount that is burned relative to the total amount of waste treated which is a default of 0.6 (IPCC, 2006); 365 is number of days in a year and10-6 is conversion factor from kilogram to Gigagram. The calculation of $\mathrm{CH}_{4}$ emissions was based on the amount of waste open-burned and on the related emission factor as shown in the following equation (Eq. 4):

$\mathrm{CO}_{2}$ Emissions $(\mathrm{Gg} / \mathrm{yr})=\Sigma_{i}\left(I W_{i} * E F_{i}\right) * 10^{-6}$

The $\mathrm{IW}_{\mathrm{i}}$ is the amount of solid waste of type i open-burned; $\mathrm{EF}_{\mathrm{i}}$ is aggregate $\mathrm{CH}_{4}$ emission factor, i.e. $\mathrm{kg} \mathrm{CH}_{4} / \mathrm{Gg}$ of waste $=6.5 \mathrm{~kg}$ / Gg (EIIP, 2001); 10-6is conversion factor from kilogram to Gigagram while i represents category or type of waste open burned. In addition, $\mathrm{N}_{2} \mathrm{O}$ emission estimate was based on influencing factors as shown in Eq. 5:

$N_{2}$ OEmissions $(G g / y r)=\Sigma_{i}\left(I W_{i} * E F_{i}\right) * 10^{-6}$ Eq. 5

In this expression, $\mathrm{EF}_{\mathrm{i}}$ is $\mathrm{N}_{2} \mathrm{O}$ emission factor $\left(\mathrm{kg} \mathrm{N} \mathrm{N}_{2} \mathrm{O} / \mathrm{Gg}\right.$ of waste) for waste of type i (a default value of $150 \mathrm{~g} \mathrm{~N}_{2} \mathrm{O} / \mathrm{t}$ waste was used- IPCC, 2006) (Table 1).

\section{Modeling of rainfall and prediction of flooding in the study area}

Rainfall data collected monthly over 44 years (1971-2014) by the Nigerian Meteorological Agency (N.I.M.E.T) was analyzed and used in the prediction of flooding in the study area. The data were first subjected to some descriptive statistics and, the gamma and Weibull distribution was then fit to the rainfall experience using the method of maximum likelihood. Also, probability of exceed- 
ances was obtained with respective return periods for amount of rainfall that could lead to flooding (Eqs. 6-12). Trend analysis on rainfall experience was done by regressing the rainfall amount on time using a regression equation (Eq. 6):

$Y=\alpha+\beta X$

Where $\mathrm{Y}=$ rainfall amount in each year, $\mathrm{X}=$ time or year, $\alpha=$ amount of rainfall when time is not considered to influence rainfall, $\beta=$ effect of time on rainfall and $\alpha, \beta$ are to be estimated. The Gamma probability distribution function is given by:

$f(X=x)=\frac{X^{\alpha-1} e^{-\frac{x}{\beta}}}{\beta^{\alpha} \Gamma \alpha} 0<X<\infty, \alpha, \beta>0$

The Weibull probability distribution function is given by:

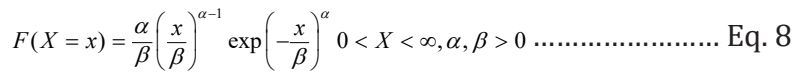

Where $\mathrm{X}$ represents rainfall amount and $f(X=x)$ represents the chance or probability that ' $x$ ' particular of rain would fall. The cumulative distribution functions given in equations below (Eqs. 9 -10) were used in the calculation of the probability that rainfall would exceed normal in subsequent years leading to flooding (probability of exceedance) (Eq. 11) and its corresponding time of occurrence (return period) (Eq. 12). The incomplete Cumulative function for the Gamma distribution is given by:

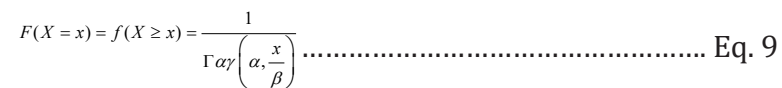

The Cumulative distribution function for the Weibull distribution is given by: $1-\exp \left(-\frac{x}{\beta}\right)^{\alpha}$
The probability of exceedance and the return period were therefore expressed as follows:

Prob of exceedance $=P_{e}=1-C D F(x)$.

return period $=T=1 / P_{e}$

\section{Results and Discussion}

\section{Ambient air quality in the community}

The results of ambient air quality as regards GHGs and temperature in the community are shown in Table 2. According to Shirmohammadi [14] \& Salahi et al. [15], temperature is one of the most important and decisive climatic factors suitable for tracking climatic changes. More values of the gases were found in the vicinity of the dump site than the points far away, which may be due to dilution of the gases with fresh air. Though the temperature was higher at $10 \mathrm{~m}$ away from the dumpsite, there was no significant difference in the temperature across the community. Figures 4-6 depict pattern of GHGs distribution in the community. The $\mathrm{CH}_{4}$ ranges from the lowest value (Green) followed by yellow, brown and red. In Figure 5, the darker the maroon colour, the more the concentration of $\mathrm{NO}_{2}$. The same explanation can be made for the Figure $6\left(\mathrm{CO}_{2}\right)$. In general, most of the GHGs were found either horizontally $\left(\mathrm{CH}_{4}\right.$ in a range of $21-22 \mathrm{ppm} ; \mathrm{CO}_{2}$ in a range of 597$634 \mathrm{ppm}$ and $\mathrm{NO}_{2}$ in a range of $20-16 \mathrm{ppm}$ ) or vertically (applicable to $\mathrm{NO}_{2}$ alone) along the dumpsite. The mechanism for the distribution exhibited by various gases is not yet fully known. However, wind direction, topography of the area, other anthropogenic activities such as open burning of waste and road traffic activities could be accountable for the variation.

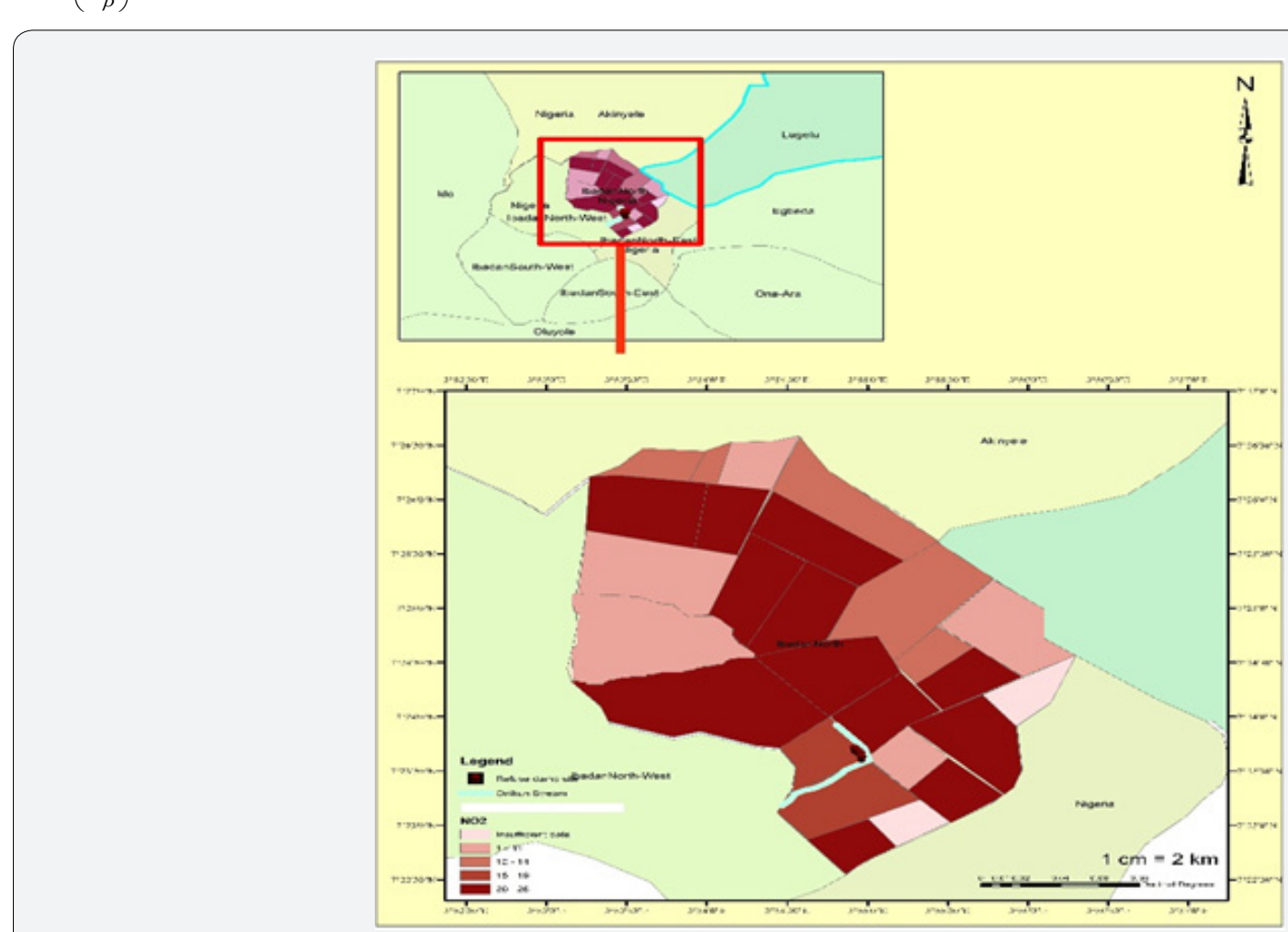

Figure 5: Pattern of $\mathrm{NO}_{2}$ distribution in the community. 


\section{International Journal of Environmental Sciences \& Natural Resources}

Table 2: Greenhouse gases and temperature levels in the community.

\begin{tabular}{|c|c|c|c|c|}
\hline Location & $\mathbf{C O}_{\mathbf{2}} \mathbf{( \mathbf { p p m } )}$ & $\mathbf{C H}_{\mathbf{4}} \mathbf{( \% )}$ & $\mathbf{N O}_{\mathbf{2}} \mathbf{( \mathbf { p p m } )}$ & $\mathbf{T e m p}\left({ }^{\mathbf{}} \mathbf{C}\right)$ \\
\hline Dumping site $(0 \mathrm{~m})$ & $607.25 \pm 21.47 \mathrm{a}$ & $18.25 \pm 5.68 \mathrm{a}$ & $23.25 \pm 2.99 \mathrm{a}$ & $34.05 \pm 0.73 \mathrm{ab}$ \\
\hline Distance of 10m away from dumping site & $535.50 \pm 9.15 \mathrm{~b}$ & $16.00 \pm 3.74 \mathrm{a}$ & $11.75 \pm 1.71 \mathrm{~b}$ & $35.33 \pm 1.43 \mathrm{a}$ \\
\hline Distance of 100m away from dumping site & $514.25 \pm 3.78 \mathrm{~b}$ & $0.50 \pm 0.14 \mathrm{~b}$ & $8.25 \pm 1.71 \mathrm{~b}$ & $33.33 \pm 1.24 \mathrm{~b}$ \\
\hline
\end{tabular}

The levels of GHGs obtained in this study were far higher than the levels obtained by Anumita et al. [29] at some locations in Abuja, Nigeria: $\mathrm{NO}_{2}(0.14 \mathrm{ppm})$ and $\mathrm{CH}_{4}(0.01 \mathrm{ppm})$. Njoku et al. [24] found $\mathrm{NO}_{2}$ at a range of $0.0-3.0 \mathrm{ppm}$ in the metropolitan city of Lagos, Nigeria, which was lower than the value obtained in this study. The levels of GHGs were also higher than regulatory limits: 4 ppm for $\mathrm{CO}_{2}$ (The Kenyan Environmental Management and Coordination (air quality) Regulations, 2014) [25]; 0.14ppm for $\mathrm{NO}_{2}$ and $0.01 \mathrm{ppm}$ for $\mathrm{CH}_{4}$ (Federal Ministry of Environment Nigeria,
2015) and tolerant limit of $0.313 \mathrm{ppm}$ (1h exposure time average) for $\mathrm{NO}_{2}[25]$.

Table 3 shows values obtained for the AQI in the community. The AQI is a rating scale for outdoor air; the lower the AQI value, the better the air quality. All the data obtained were in very poor category (100 and over), which meant that air was highly polluted in the community. At these levels, the sensitive vulnerable groups such as children and pregnant women may be at risk of various environmental health hazards.

Table 3: Air Quality index in the community.

\begin{tabular}{|c|c|c|c|}
\hline Location & $\mathrm{CO}_{2}$ & $\mathrm{CH}_{4}$ & $\mathrm{NO}_{2}$ \\
\hline Dumping site $(0 \mathrm{~m})$ & $15,181.25$ & 182,500 & $16,607.14$ \\
\hline Distance of $10 \mathrm{~m}$ away from dumping site & $13,387.50$ & 160,000 & $8,392.86$ \\
\hline Distance of $100 \mathrm{~m}$ away from dumping site & $12,856.25$ & 5000 & $5,892.86$ \\
\hline Kenyan Environmental Management and Coordination on air quality regulations (2014) & 4 & - & - \\
\hline Federal Ministry of Environment Nigeria (2015) & - & 0.01 & 0.14 \\
\hline
\end{tabular}

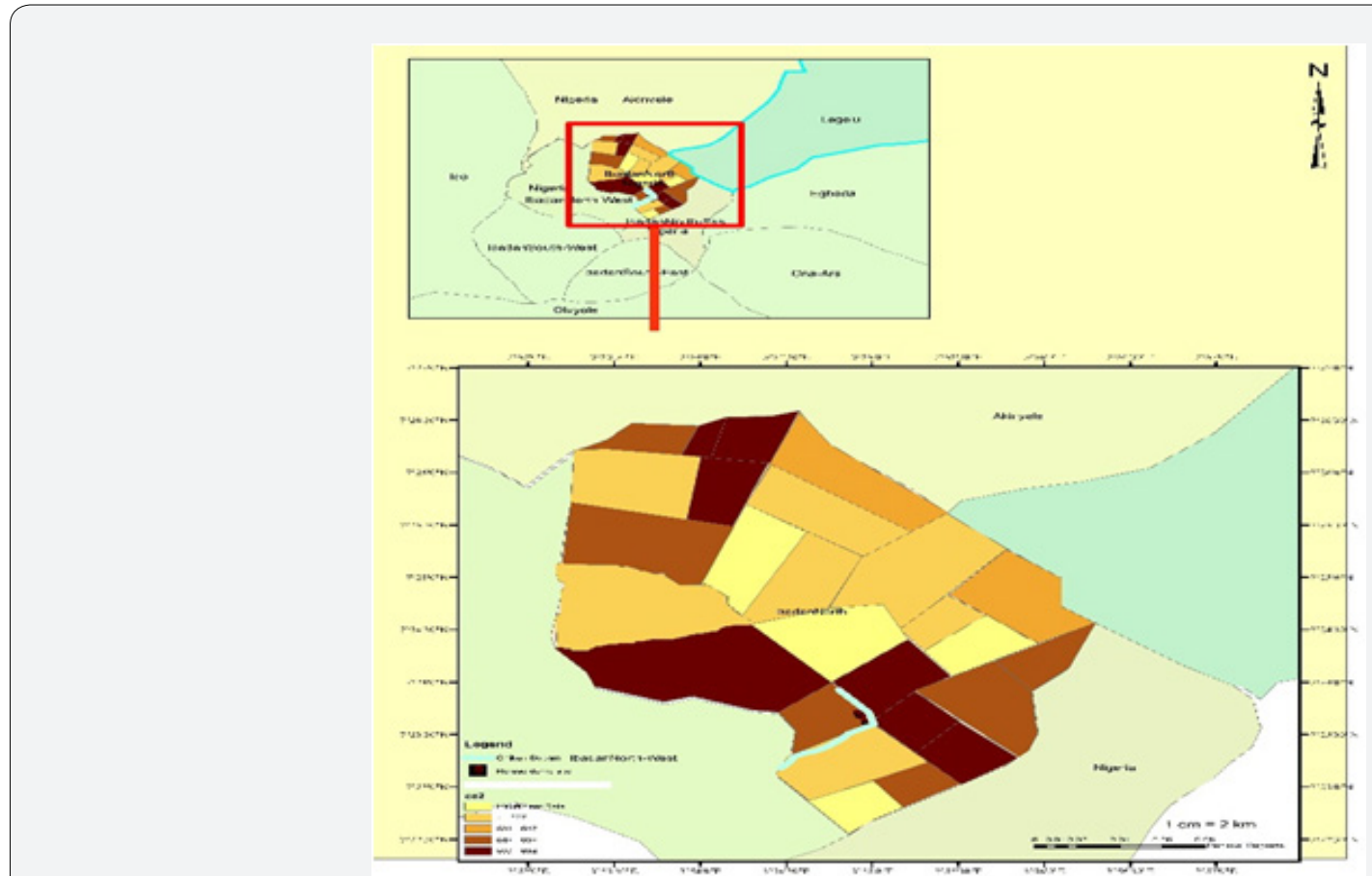

Figure 6: Pattern of $\mathrm{CO}_{2}$ distribution in the community.

\section{GHG emission potential of solid waste burning}

Carbon dioxide is a major greenhouse gas attributed to open burning of waste in the community as shown in Figure 7. In one year, burning of waste can introduce $70,000 \mathrm{Gg} / \mathrm{yr}$ which may be potentially harmful to the inhabitants. For now, there are no actions to prevent open burning of municipal waste and agricultural waste in the country as a whole. The UNEP [30] described coun- try-level policies in relation to standards on national ambient air quality and concluded that there was scanty information on air quality policy and standards in Nigeria. Air pollution is regulated by four major regulations issued by the National Environmental Standards and Regulation Enforcement Agency (NESREA). These are: The National Guidelines and Standards for Environmental Pollution Control in Nigeria, National Environmental Protection 
(pollution abatement in industries and facilities that generate wastes) Regulation 1991, the Management of Solid and Hazard- ous Wastes Regulations 1991 and the recent National Solid Waste Management Policy (2017) [31, 32].

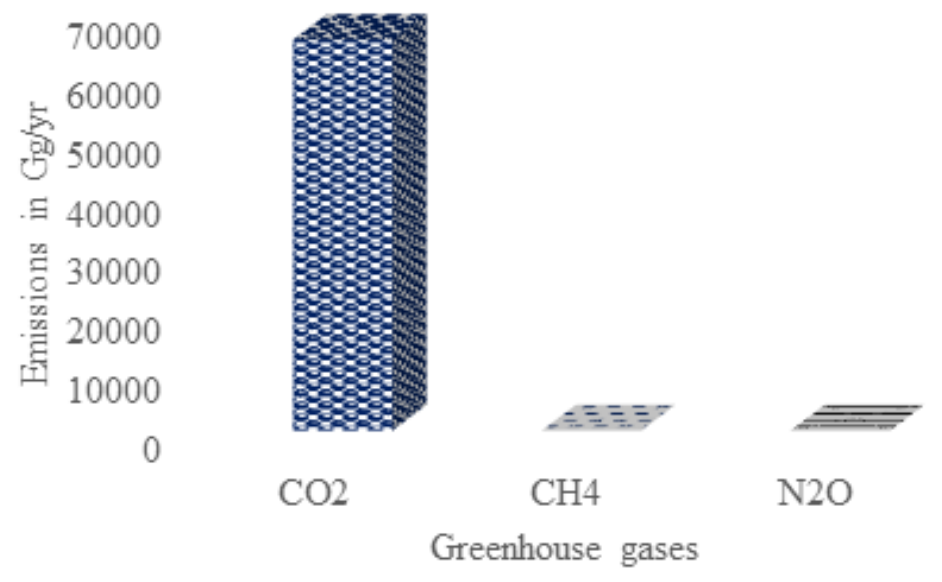

Figure 7: Greenhouse gas emission potential of open burning of waste in the community in a year.

\section{Modeling of rainfall and prediction of flooding in the study area}

The available statistics on rainfall pattern in Ibadan shows minimum rainfall in 1971 (622.5mm) and maximum rainfall in
1980 (1944.40mm), with a mean of 1293.2mm within 1971-2014. Graphical representation of rainfall experience within these years is shown in Figure 8. There is variability in the trend of rainfall over the years, indicating rainfall increase over the years.

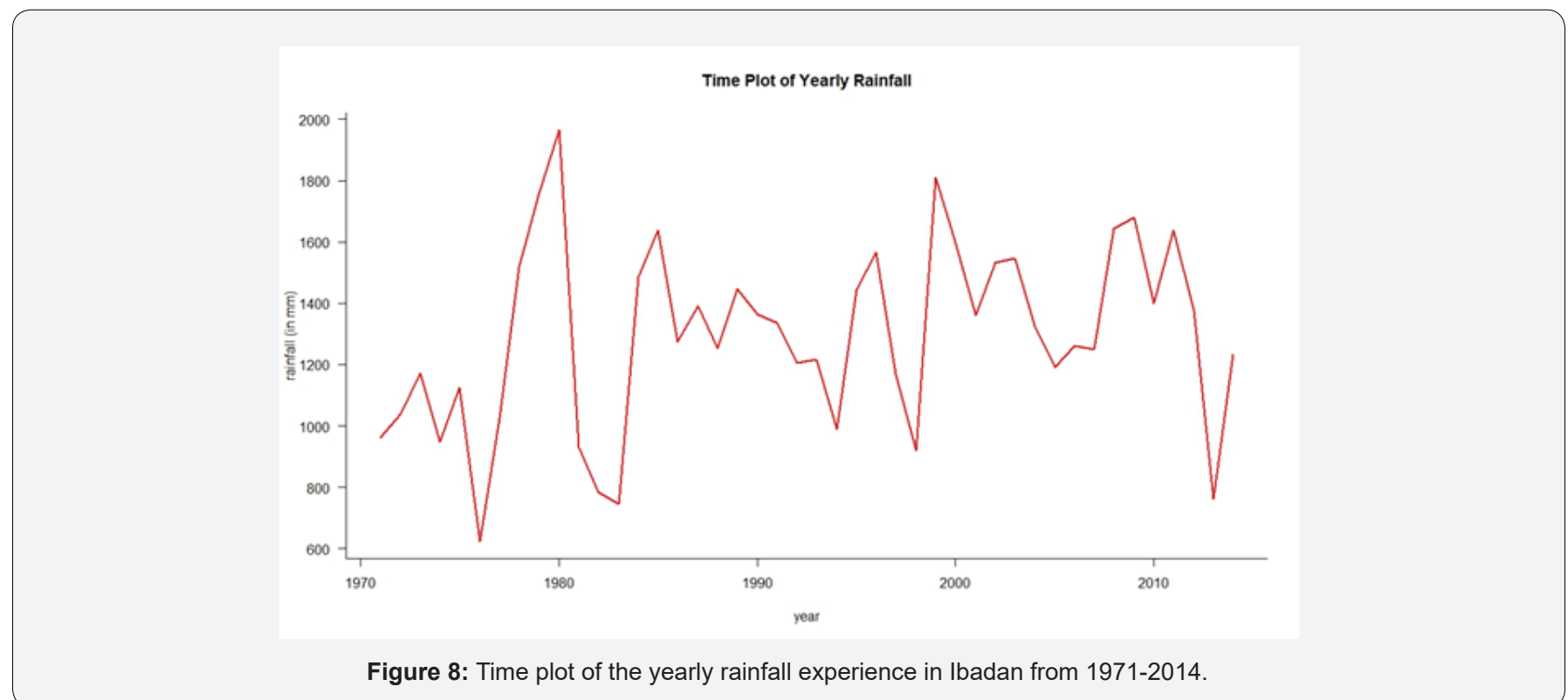

After estimation, our regression line was given as (Eq. 13):

Rainfall $=-12143.901+6.744 *$ time ..Eq. 13

Since $\beta=6.744$ is positive, we can then say there exists an upward trend in the rainfall experience i.e. rainfall increases over time and would result in flooding if there is no proper management. To explain the probability distribution of the rainfall experience and flooding in the project area, results of goodness fit test and probability of exceedance and return periods are shown in Tables 4 \& 5. Since the 'p-value' for the Weibull distribution is larger than that of the Gamma distribution, the Weibull is a better fit, more reliable than the Gamma, for the rainfall and flooding prediction in the area.

From the above, it is evident that the Rainfall in the project area increases over time. As a result, there is possibility of rainfall exceeding the amount the environment can hold. That is, in 3 years from 2014 upward, there is about $40 \%$ chance of rainfall exceeding the threshold of $1400 \mathrm{~mm}$ annually. This could lead to flooding in the study area if there is no proper management plan 
put in place. Inah et al. [17] also observed a general increasing trend in rainfall pattern for Calabar, an urban area in south-south Nigeria, using common geo-referenced model factors such as, sea level rise, increased and annual precipitation. However, the findings of this study are not in consonance with a recent study conducted in Iran by Salahi et al. [15] who found a decrease of about $26 \mathrm{~mm}$ with regard to the average of monthly precipitation in the next 10 years while modelling precipitation characteristics in the area. A previous study by Joseph et al. [23] in the study area linked waste management practices and poorly sized drainages to Table 4: Probability distribution of rainfall for prediction of flooding. principal causes of flooding and erosion in the area. Their study proposes well-designed drainage/culvert with enough hydraulic capacity as a lasting engineering solution to accommodate runoff being generated from the community. Also, in their findings, Agbola et al. [19] concluded that dumping of refuse in rivers and drainage channels could have been responsible for the 2011 flooding in the city of Ibadan. As a result, one of plans to reduce flooding as an aftermath of imminent heavy downpour is to put in place proper waste management since the practice of dumping wastes in drainage and river channels is common in the city areas [33, 34].

\begin{tabular}{|c|c|c|c|c|c|c|c|}
\hline \multirow{2}{*}{ Location } & \multicolumn{7}{|c|}{ Gamma Distribution } \\
\hline & $\alpha$ & $\beta$ & $\chi$ statistics & df & p-value & sig. value & Fit/Not Fit \\
\hline Ibadan & 16.7304 & 0.0129 & 6.3069 & 4 & 0.1774 & 0.05 & YES \\
\hline \multirow[t]{2}{*}{ Location } & \multicolumn{7}{|c|}{ Weibull Distribution } \\
\hline & $\alpha$ & $\beta$ & $\chi$ statistics & df & p-value & sig. value & Fit/Not Fit \\
\hline Ibadan & 4.8687 & 1411.272 & 4.0244 & 4 & 0.4027 & 0.05 & YES \\
\hline
\end{tabular}

Table 5: Probability of exceedance and return periods.

\begin{tabular}{|c|c|c|c|c|c|c|}
\hline Location & Distribution & $\boldsymbol{\alpha}$ & $\boldsymbol{\beta}$ & Threshold (in mm) & Pe & T (in years) \\
\hline Ibadan & Gamma & 16.7304 & 0.0129 & 1400 & 0.3453 & 3 \\
\hline & Weibull & 4.8687 & 1411.272 & 1400 & 0.3822 & 3 \\
\hline
\end{tabular}

\section{Conclusion}

The outdoor air quality was very poor, and the levels of waste induced emissions were more than regulatory limits. Greenhouse gases reduced with distance away from the dumpsite not evenly distributed and concentrated horizontally along the dumpsite in the community. In one year, burning of waste can introduce $70,000 \mathrm{Gg} / \mathrm{yr}$ of $\mathrm{CO}_{2}$ which may be potentially harmful to the inhabitants. There is possibility of rainfall exceeding the amount the environment can contain. That is, in three years from 2014 upward, there is about $40 \%$ chance of rainfall exceeding the threshold of $1400 \mathrm{~mm}$ annually. This could lead to flooding in the area if there are no proactive actions and proper management plans. We therefore recommend that contingency plans such as proper waste management be put in place to avoid blockage of drainage systems and reduce the aftermath of the imminent heavy downpour in the area.

\section{References}

1. Nkwunonwo UC, Malcolm W, Brian B (2015) Flooding and Flood RiskReduction in Nigeria Cardinal Gaps. Journal of Geographical Natural Disaster. 5: 136- 145.

2. NEMA (Nigeerina Emergency Manageent Agency) (2013) Report on flood disasters in Nigeria. Abuja: Government Press.

3. IRIN (2012) Synopsis of flood damage.

4. ActionAid (2006) Climate change, urban flooding and the rights of the urban poor in Africa: Key findings from six African cities. Action Aid International, London, UK.

5. Cline WR (2007) Global Warming and Agriculture. Centre for Global Development, Peterson Institute for International Economics, Washington, DC, USA.
6. Adeloye AJ, Rustum R (2011) Lagos (Nigeria) flooding and influence of urban Planning. Urban Design and Planning 164: 175-187.

7. Houston D, Werritty A, Bassett D, Geddes A, Hoolachan A, et al. (2011) Pluvial (Rain-Related) Flooding in Urban Areas: the Invincible Hazard. Joseph Rowntree Foundation, UK.

8. Ijigah EA, Akinyemi TA (2015) Flood Disaster: An Empirical Survey of Causative Factors and Preventive Measures in Kaduna, Nigeria. International Journal of Environment and Pollution Research 3(3): 53-66.

9. Odunuga S, Oyebande L, Omojola AS (2013) Social-economic indicators and public perception on urban flooding in LagosHydrology for Disaster Management. Special Publication of the Nigerian Association of Hydrological Sciences, NAHS, Abuja, pp. 82-96.

10. Aderogba K (2012) Global warming and challenges of floods in Lagos metropolis, Nigeria. Academic Research International 2(1): 448- 468.

11. Eguaroje OE, Alaga TA, Ogbole JO, Omolere S, Alwadood J, et al. (2015) Flood Vulnerability Assessment of Ibadan City, Oyo State, Nigeria. World Environment 5(4): 149-159.

12. Lamond J, Bhattacharya N, Bloch R (2012) The role of solid waste management as a response to urban flood risk in developing countries, a case study analysis. In: Proverbs D, Mambretti S, Brebbia C, de Wrachien D (Eds.), Flood Recovery Innovation and Response, WIT Press, Southampton, England, pp. 193-205.

13. IPCC (2006) IPCC Guidelines for National Greenhouse Gas Inventories, Prepared by the National Greenhouse Gas Inventories Programme. In: Eggleston HS, Buendia L, Miwa K, Ngara T, Tanabe K (Eds.), IGES, Japan.

14. Shirmohammadi S (2012) Investigation and modeling of temperature time series in Zanjan (1956-2005). Geographical Research 27(4): 3358.

15. Salahi B, Nohegar A, Behrouzi M (2016) The Modeling of Precipitation and Future Droughts of Mashhad Plain using Stochastic Time Series and Standardized Precipitation Index (SPI). International Journal of Environmental Resources 10(4): 625-636. 
16. Kaoje IU, Ishiaku I (2017) Urban Flood Vulnerability Mapping of Lagos, Nigeria. International Journal of Science and Technology 3(1): 224236.

17. Inah EO, Chima OO, Marcus AI, David DE, Richard OS (2015) Climate change and the challenges of flood mitigation in Calabar urban, southsouth Nigeria. International Journal of Ecology and Ecosolution 2(3): 41-48.

18. Peter CN, Nihinlola OD, Ayila EA (2012) Flood Modelling and Vulnerability Assessment of Settlements in the Adamawa State Floodplain Using GIS and Cellular Framework Approach. Global Journal of Human Social Science 12(3): 11-20.

19. Agbola B, Ajayi O, Taiwo O, Wahab B (2012) The August 2011 flood in Ibadan, Nigeria: Anthropogenic causes and consequences. International Journal of Disaster Risk Science 3(4): 207-217.

20. Adegbola AA, Jolayemi JK (2012) Historical rainfall-runoff modeling of river Ogunpa, Ibadan, Nigeria. Indian Journal of Science and Technology 5(5): 2725-2728.

21. Adelekan IO (2011) Vulnerability assessment of an urban flood in Nigeria: Abeokuta flood 2007. Natural Hazards 56(1): 215-231.

22. Odufuwa BO, Adedeji OH, Oladesu JO, Bongwa A (2012) Floods of fury in Nigerian cities. Journal of Sustainable Development 5(7): 69-79.

23. Joseph SO, Sridhar MKC, Coker AO (2017) Causes and Prevention of Flooding and Erosion in Urban Centres: A Study of Kube-Atenda Community, Ibadan North Local Government Area, Oyo State. International Journal of Scientific and Engineering Research 8(3): 1139- 1158.

24. Njoku KL, Rumide TJ, Akinola MO, Adesuyi AA, Jolaoso AO (2016) Ambient Air Quality Monitoring in Metropolitan City of Lagos, Nigeria. Journal of Applied Science and Environmental Management 20(1): 178-185.
25. United States Environmental Protection Agency (USEPA) (2006) Air Pollutants.

26. The Kenyan Air Quality Regulations (2014) Kenya Gazette Supplement No. 41 (Legislative Supplement No.15).

27. Federal Ministry of Environment Nigeria (2015) Nigeria National Air Quality Management Program.

28. Hammed TB, Shem OW, Yacob M, Sridhar MKC (2018) Improving Knowledge and Practices of Mitigating Green House Gas Emission through Waste Recycling in a Community, Ibadan, Nigeria. Waste Management 81: 22-32.

29. Anumita R, Usman N, Priyanka C (2016) Ambient air quality standards and compliance strategy'. In: Archana Shankar (Ed.), Towards Clean Air in Nigerian Cities. Centre for Science and Environment, New Delhi, India, pp. 11-12.

30. UNEP (2015) Nigeria Air Quality Policies.

31. National Population Commission (NPC) (2006) Records of the NPC Census reports.

32. Federal Republic of Nigeria (2017) National Policy on Solid Waste Management, Draft Policy, pp. 1-92.

33. Olaseha IO, Sridhar MKC (2004) Community Mobilization for Drainage Improvement: Experience from Three Communities in Ibadan, Nigeria. International Quarterly of Community Health Education 22(10): 77 85.

34. R Core Team (2017) R, A language and environment for statistical computing. R Foundation for Statistical Computing, Vienna, Austria.

Your next submission with Juniper Publishers will reach you the below assets

- Quality Editorial service

- Swift Peer Review

- Reprints availability

- E-prints Service

- Manuscript Podcast for convenient understanding

- Global attainment for your research

- Manuscript accessibility in different formats ( Pdf, E-pub, Full Text, Audio)

- Unceasing customer service

Track the below URL for one-step submission https://juniperpublishers.com/online-submission.php 